\title{
Phenotypic Correlation Between Body Measurements in Saudi Sheep in Qassim Region
}

\author{
Elzarei $\mathrm{MF}^{1,2}$, Mousa $\mathrm{EF}^{1,3}$ and AL-Sharari $\mathrm{SA}^{1}$ \\ ${ }^{1}$ Animal Production and Breeding Department, College of Agriculture and Veterinary Medicine, Qassim \\ University, Saudi Arabia \\ ${ }^{2}$ Animal Production Department, Faculty of Agriculture, Suez Canal University, Ismailia, Egypt. \\ ${ }^{3}$ Animal Production Department, Faculty of Agriculture, Assiut University, Assiut, Egypt. \\ Correspondence: Elzarei MF, Animal Production and Breeding Department, College of Agriculture and \\ Veterinary Medicine, Qassim University, Saudi Arabia. Tel: +966-16-380 0050-16213. E-mail: \\ zray@qu.edu.sa
}

Received: March 31, 2020

Accepted: April 8, $2021 \quad$ Online Published: June 30, 2021

doi:10.5539/ijb.v13n1p26

URL: doi: 10.5539/ijb.v13n1p26

\begin{abstract}
Identify the genetic resources of the sheep and characterize these breeds accurately are very important to enhance the good performances of sheep and expand the knowledge of the differences among those breeds. Body measurements therefore, are perfect indicators to make definition for each breed. The present study is part of a wide one to definite of phenotypic characteristics in local breeds of sheep in Qassim region, Kingdom of Saudi Arabia. The data were collected from three breeds in Qassim region, Noemi, Najdi and Hari. Najdi is the biggest breed of the sheep breeds in Saudi Arabia and it is the main breed in Najd region. Noemi is taking the second size breed of the sheep breeds in Saudi Arabia. Hari is the smallest breed of sheep breeds in Saudi Arabia, it is the main breed in Hejaz and Assir regions, which belong to the sheep with coarse hair, and thick tail strain. Eight body measurements traits were studied, Wither heights (WH), Rum heights (RH), Body length (BL), Head length (HL), Heart girth (HG), Muzzle diameter (MD), Cannon circumference (CC) and Cannon length (CL).

The correlations coefficients among all studied traits were moderate to high and highly significant. The highest correlation coefficient was found between RH and WH traits (0.872), and the lowest one was found between CC and HG traits $(0.214)$. The correlations coefficients between relative traits can help us to understand the similarity among studied traits and can be used in the future in selection program.
\end{abstract}

Keywords: Wither heights, Rum heights, Body length, Head length, Heart girth, Muzzle diameter, Cannon circumference and Cannon length

\section{Introduction}

Many researchers give an attention to the body measurements of sheep as good indicators of growths. Body measurements are necessary data sources in terms of reflecting the breed standards, Riva et al., (2004) and are important in giving information about the morphological structure and development ability of the animals. Body measurements differ according to the factors such as breed, gender, yield type and age, Shirzeyli et al., (2013). Highly significant correlations were reported in most studies between linear body measurements and live body weight (Otoikhian et al., 2008, Moneim et al., 2009). Body measurements have also been used to differentiate and identify the Saudi local breed as a phenotypic characterization (Suparyanto et al., 1999, Mansjoer et al, 2007). The phenotypic characterization in sheep can be measured through body size, which can be used for visual identification and to determine the idea growth of the animal (Ghahri et al., 2019, Widi, et al., 2016).

Serval body measurements such as height at withers (WH), body length (BL), heart girth (HG), are corelated and can be used to predict body weight and describe the performance of sheep (Hardjosubroto, 1994, Iqbal et al., 2019). Body measurements were easy to measure compare with body weight, which need weighting, scale while surveying farms. Classify genetic resources of sheep and characterize these breeds accurately, maintain and increase the numbers of good performances animals, knowing the different production patterns in the Kingdom and the distribution of species in the regions and cities and different economic production systems This will enable 
us to increase this important agricultural production sector in the Kingdom. To date, there is no specific scientific description known to our local breeds as is known to all other breeds around the world.

\section{Material and Method}

This study was carried out in Animal Production and breeding department, College of Agriculture and Veterinary Medicine, Qassim University, Qassim region, Saudi Arabia.

A total of 1992 records from 294 animal of three different local breeds: 96 Noemi, 108 Najdi and 90 Hari for male and female was used in the current study, data were collected from College of Agriculture and Veterinary Medicine experimental station and some private farms in Qassim region.

Body measurements had taken in a standing position of the sheep. Eight characters of body measurements were taken by using a metric tape and cattle height hip measuring stick. Eight body measurements traits were used in the studied traits, Wither heights (WH), Rum heights (RH), Body length (BL), Head length (HL), Heart girth (HG), Muzzle diameter (MD), Cannon circumference (CC) and Cannon length (CL).

Table 1: Summarize of collected data.

\begin{tabular}{|c|c|c|c|c|c|c|}
\hline Breed & Sex & $\begin{array}{l}\text { Age } \\
8 \text { months }\end{array}$ & 18 months & 48 months & Total & \\
\hline \multirow[t]{2}{*}{ Noemi } & Male & 20 & 4 & 9 & 33 & \multirow{2}{*}{96} \\
\hline & Female & 16 & 21 & 26 & 63 & \\
\hline \multirow[t]{3}{*}{ Najdi } & Male & 16 & 23 & 6 & 45 & \multirow{2}{*}{108} \\
\hline & Female & 23 & 22 & 18 & 63 & \\
\hline & Male & 17 & 9 & 7 & 33 & 90 \\
\hline Hari & Female & 18 & 19 & 20 & 57 & \\
\hline Overall & & 110 & 98 & 86 & 294 & \\
\hline
\end{tabular}

\subsection{Statistical Analysis}

SAS software Ver.9.0 (SAS, 2002) was used for analysis of variance of quantitative traits. Estimation the least square mean for different measurements traits and analysis of variance for three-fixed effect of sex, age and breed. The modal used as:

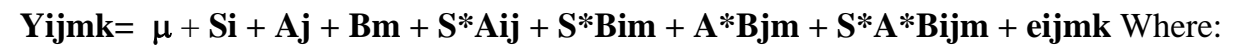

$\mu$ : is the overall mean;

$S$ : is the fixed effect of the sex where $i=2$;

A: is the fixed effect of the age where $j=3$;

$B$ : is the fixed effect of the breed where $m=3$;

$S^{*} A$ : is the interaction between sex and age where $i j=6$;

$\mathrm{S} * \mathrm{~B}_{\mathrm{im}}$ : is the interaction between sex and breed where $\mathrm{im}=6$;

$A * B_{j m}$ : is the interaction between age and breed where $\mathrm{jm}=9$;

$\mathrm{S}^{*} \mathrm{~A} * \mathrm{~B}_{\mathrm{um}}$ : is the 3 terms of interaction among age, breed and sex where um $=18$ and $e_{\mathrm{ijmk}}=$ random error

Phenotypic correlation is the Pearson correlation coefficient between two body measurements the same animal and estimated by formula:

$$
\text { Correlation }=\frac{\operatorname{Cov}_{(X, Y)}}{\sigma_{X} * \sigma_{Y}}
$$

$\operatorname{Cov}_{(x, y)}=$ covariance of the variables $x$ and $y$

$\sigma_{x}=$ sample standard deviation of variable $x$

$\sigma_{y}=$ sample standard deviation of variable $y$ 


\section{Results and Discussion}

Table 2, showed the correlation coefficients between the eight studied traits. As shown in table, the highest value of the correlation coefficient was found between wither heights and rum heights $(0.872, p \leq 0.001)$. By the other way, the lowest value of the correlation coefficient was found between heart girth and cannon circumference $(0.214, p \leq 0.001)$. In general, the positive moderate to high correlations coefficients between relative traits are so important in selection program meaning that improve one trait improve the others.

In this respect, the highest value of correlations items sorted by ascending were $0.872,0.861,0.799,0.794,0.755$, 0.773, 0.723, 0.677, 0.692, 0.661, 0.640, 0.639 and 0.629, between (RH, WH), (MD, HL), (CL, HL), (CC, HL), (CL, MD), (BL, WH), (BL, RH), (CC, MD), (MD, BL), (HG, WH), (HL, BL), (HG, RH) and (HG, BL), respectively. The phenotypic correlation between (WH, BL), (WH, HG), (WH, CL), (RH, BL), (RH, HG), (RH, $\mathrm{CL}),(\mathrm{BL}, \mathrm{HG}),(\mathrm{BL}, \mathrm{CL}),(\mathrm{HG}, \mathrm{CL})$ were $0.77,0.69,0.43,072,0.64,0.46,0.63,0.56$ and 0.41 , respectively.

These results are similar to that found by other researcher, for example Jafari et al., (2014) reported moderate correlation coefficient.

Also, Taye et al., (2016) in their work found that the phenotypic correlation between studied traits was high to moderate the coefficients values were, $0.85,0.68,0.66,0.57,0.56$ and 0.56 between (WH\&RH), (WH\&HG), (RH\&HG), (BL\&WH), (BL\&RH), (BL\&HG), respectively.

In addition, Feyissa et al., (2018) figured out that the correlation coefficients between (WH, BL), (WH, HG), (WH, CC) (BL, WH), (BL, HG), (BL, CC), (HG, WH), (HG, BL), (HG, CC), (CC, WH), (CC, BL), (CC, HG), were 0.39, $0.63,0.32,0.45,0.39,0.22,0.40,0.41,0.42,0.43,0.24$ and 0.51 , respectively.

The moderate to high favorable coefficients of correlation between studied traits led us to say that the genetic improvements are at the same time can be made simply to improve one trait and we can gain the improvements in the other traits.

Table 2. Correlations coefficients between studied traits

\begin{tabular}{|c|c|c|c|c|c|c|c|c|}
\hline & WH & RH & BL & HL & HG & MD & $\mathrm{CC}$ & $\mathrm{CL}$ \\
\hline WH & & $.872 * * *$ & $.773^{* * *}$ & $.535^{* * *}$ & $.692 * * *$ & $.587 * * *$ & $.222 * * *$ & $.437 * * *$ \\
\hline RH & & & $.723^{* * *}$ & $.542 * * *$ & $.639 * * *$ & $.538 * * *$ & $.226 * * *$ & $.464 * * *$ \\
\hline $\mathrm{BL}$ & & & & $.640 * * *$ & $.629 * * *$ & $.661 * * *$ & $.281 * * *$ & $.561 * * *$ \\
\hline HL & & & & & $.538 * * *$ & $.861 * * *$ & $.794 * * *$ & $.799 * * *$ \\
\hline $\mathrm{HG}$ & & & & & & $.587 * *$ & $.214 * * *$ & $.415^{* * *}$ \\
\hline MD & & & & & & & $.677 * * *$ & $.755^{* * * *}$ \\
\hline $\mathrm{CC}$ & & & & & & & & $.638 * * *$ \\
\hline
\end{tabular}

***Correlation is significant at the 0.001 level.

Wither heights (WH), Rum heights (RH), Body length (BL), Head length (HL), Heart girth (HG), Muzzle diameter (MD), Cannon circumference (CC) and Cannon length (CL).

\section{Conclusion}

Positive moderate to high correlations coefficients between the eight studied traits. This gives us the opportunity to save time and make selection more accurate.

\section{References}

Feyissa, A., Kebede, A., Kefeni, K., and Amaha, N. (2018). Application of Body Measurements of Blackhead Somali Sheep as Parameters for Estimation of Live Weight. Iranian Journal of Applied Animal Science, 8(4), 647652.

Ghahri, B., Alijani, S., Rafat, S., Nabavi, R., and KIA, H. (2019). Genetic appraisal of growth traits in Iranian native Ghezel sheep using random regression models. Turkish Journal of Veterinary and Animal Sciences, 43(3), 372379. 
Hardjosubroto, W. (1994). Aplikasi pemuliabiakan ternak di lapangan. Gramedia Widiasarana Indonesia, Jakarta.

Iqbal, F., Ali, M., Huma, Z., and Raziq, A. (2019). Predicting live body weight of harnai sheep through penalized regression models. J. Anim. Plant Sci, 29(6), 1541-1548.

Jafari, S., Hashemi, A., Darvishzadeh, R., and Manafiazar, G. (2014). Genetic parameters of live body weight, body measurements, greasy fleece weight, and reproduction traits in Makuie sheep breed. Spanish journal of agricultural research, (3), 653-663.

Mansjoer, S., Kertanugraha, T., and Sumantri, C. (2007). Estimasi Jarak Genetik antar Domba Garut Tipe Tangkas dengan Tipe Pedaging. Media Peternakan, 30(2): 129-138.

Moneim, A. (2009). Use of live body measurements for prediction of body and carcass cuts weights in three Egyptian breeds of sheep. Egypt. J. Sheep Goat Sci, 4(2), 17-32.

Otoikhian, C., Otoikhian, A., Akporhuarho, O., Oyefia, V., and Isidahomen, C. (2008). Body measurement parameters as a function of assessing body weight in goats under on-farm research environment. African Journal of General Agriculture, 4(3), 135-140.

Riva, J., Rizzi, R., Marelli, S., and Cavalchini, L. (2004). Body measurements in Bergamasca sheep. Small Ruminant Research, 55(1-3), 221-227.

SAS (2002), SAS Institute Inc., SAS 9.1.3 Help and Documentation, Cary, NC: SAS Institute Inc., 2002-2004

Shirzeyli, S., Lavvaf, A., and Asadi, A. (2013). Estimation of body weight from body measurements in four breeds of Iranian sheep. Songklanakarin. Journal of Science and Technology. 35(5):507-511.

Suparyanto, A., Purwadaria, T., and Subandriyo, D. (1999). Pendugaan jarak genetik dan faktor peubah pembeda bangsa dan kelompok domba di Indonesia melalui pendekatan analisis morfologi. J. Ilmu Tern. Vet. 4:80- 87.

Taye, M., Yilma, M., Rischkowsky, B., Dessie, T., Okeyo, M., Mekuriaw, G., and Haile, A. (2016). Morphological characteristics and linear body measurements of Doyogena sheep in Doyogena district of SNNPR, Ethiopia. African Journal of Agricultural Research, 11(48), 4873-4885.

Widi, T., Baliarti E., Ibrahim A., Koesmara H., Budisatria, I. (2016). Phenotypic characteristics of aceh cattle on different sex and age in smallholder farmers. $3^{\text {rd }}$ Anim. Prod. Int. Semin., pp. 381-382.

\section{Copyrights}

Copyright for this article is retained by the author(s), with first publication rights granted to the journal.

This is an open-access article distributed under the terms and conditions of the Creative Commons Attribution license (http://creativecommons.org/licenses/by/4.0/). 